\title{
PHYLOGENETIC RELATIONSHIPS OF SPECIES OF RAYMUNIDA (DECAPODA: GALATHEIDAE) BASED ON MORPHOLOGY AND MITOCHONDRIAL CYTOCHROME OXIDASE SEQUENCES, WITH THE RECOGNITION OF FOUR NEW SPECIES
}

\author{
E. Macpherson and A. Machordom
}

\begin{abstract}
(EM) Centro de Estudios Avanzados de Blanes (CSIC), Camí de Santa Bárbara s/n, 17300 Blanes, Girona, Spain (e-mail: macpherson@ceab.csic.es); (AM) Museo Nacional de Ciencias Naturales (CSIC), José Gutiérrez Abascal 2, 28006 Madrid, Spain (e-mail: mcna133@mncn.csic.es)
\end{abstract}

\section{A B S T R A C T}

\begin{abstract}
The species of the genus Raymunida from the Pacific and Indian oceans are revised using morphological characters and the mitochondrial cytochrome oxidase subunit I sequences. Four new species are described ( $R$. confundens, $R$. dextralis, $R$. erythrina, and $R$. insulata), and the status of $R$. bellior and $R$. elegantissima are revised. The species of Raymunida can be identified by subtle morphological characters, which match differences in mitochondrial nucleotide sequences. Therefore, the sequence divergences confirm the specific and phylogenetic value of some morphological characters (e.g., length of the mesial spine on the basal antennal segment, length of the walking legs). Furthermore, they confirm the importance of the color pattern as a diagnostic character. The widespread species ( $R$. elegantissima), known from the Philippines to Fiji, shows minimal divergence between specimens from different localities (maximum of 3 nucleotide differences or $0.2 \%$ mean divergence). The phylogenetic reconstruction agreed with the monophyletic condition of Raymunida and its differentiation with respect to the genus Munida (in which Raymunida species had previously been included) and Agononida.
\end{abstract}

The genus Raymunida has recently been created to include those species of the genus Munida Leach, 1820, characterised by the presence of four spines on each branchial margin of the carapace; abdominal tergites unarmed; epipods on the first, second, and third pereiopods; one spine on the frontal margin between supraocular and anterolateral spines; one distal spine on the flexor margin of the carpus of the third maxilliped; the merus of the second pereiopod clearly more slender than those of the third and fourth pereiopods; and the presence of several long marginal spines on the endopod of the uropods (Macpherson and Machordom, 2000). The genus currently contains three species recorded from numerous localities of the Pacific and Indian oceans: (1) R. elegantissima (De Man, 1902) from the eastern Indian Ocean, Malay Archipelago, Indonesia, Philippines, Japan, western and eastern Australia, New Caledonia, Bellona Island, Vanuatu and Futuna Island, between 20 and 440 m; (2) R. bellior (Miyake and Baba, 1967) from Japan, Philippines, Loyalty, Chesterfield, and Futuna Islands, between 80 and 330 $\mathrm{m}$; and (3) $R$. cagnetei from the Marquesas
Islands, between 53 and $112 \mathrm{~m}$ (Baba, 1988; Macpherson, 1994, 1996, 1999; Macpherson and Machordom, 2000). Although several morphological differences among the three species exist, very few specimens (usually 1 or 2) of $R$. elegantissima and $R$. bellior are caught in each locality, which prevents the evaluation of intraspecific morphological variations and specific characters. Furthermore, the color pattern, which differentiates many species of galatheid decapods (Macpherson, 1994), is lost in preserved material. Therefore, the identification and occurrence of $R$. elegantissima and $R$. bellior in some localities are doubtful, and a revision of these specimens has been recommended (Macpherson, 1994, 1996, 1999). For these reasons, as in other groups with dubious species (Chan and Chu, 1996; Sarver et al., 1998), we have used, in addition to morphology, molecular characters in order to provide supplementary support to the species identifications.

Molecular data are a complementary approach to morphology, especially in discriminating cryptic or sibling species (Knowlton, 1993; Sarver et al., 1998) and constructing phylogenetic relationships (Avise, 1994). Mi- 
Table 1. Species studied for mitochondrial DNA sequences, including sampling localities, expedition, station, and codes used in Figure 7 and Table 2.

\begin{tabular}{|c|c|c|c|c|c|}
\hline Code & Species & Locality & Expedition & Station & GenBank A. No. \\
\hline RCA1 & Raymunida cagnetei & Marquesas Is. & Musorstom 9 & 1177 & AF 283869 \\
\hline RCA2 & Raymunida cagnetei & Marquesas Is. & Musorstom 9 & 1177 & AF 283870 \\
\hline RCA3 & Raymunida cagnetei & Marquesas Is. & Musorstom 9 & 1177 & AF 283871 \\
\hline RCO1 & Raymunida confundens & Chesterfield Is. & Musorstom 5 & 315 & AF 283872 \\
\hline $\mathrm{RCO} 2$ & Raymunida confundens & New Caledonia & Smib 8 & 178 & AF 283873 \\
\hline RDE1 & Raymunida dextralis & Loyalty Is. & Musorstom 6 & 419 & AF 283874 \\
\hline REL1 & Raymunida elegantissima & Bellona Is. & Corail 1 & unnumbered & AF 283875 \\
\hline REL2 & Raymunida elegantissima & Wallis Is. & Musorstom 7 & 498 & AF 283876 \\
\hline REL3 & Raymunida elegantissima & Philippines & Musorstom 1 & 57 & AF 283877 \\
\hline REL4 & Raymunida elegantissima & Vanuatu & Musorstom 8 & 966 & AF 283878 \\
\hline REL5 & Raymunida elegantissima & Vanuatu & Musorstom 8 & 966 & AF 283879 \\
\hline REL6 & Raymunida elegantissima & New Caledonia & Lagon Est & 640 & AF 283880 \\
\hline REL7 & Raymunida elegantissima & Fiji & Musorstom 10 & 1363 & AF 283881 \\
\hline RER1 & Raymunida erythrina & Futuna Is. & Musorstom 7 & 515 & AF 283882 \\
\hline RER2 & Raymunida erythrina & Vanuatu & Musorstom 8 & 1077 & AF 283883 \\
\hline RIN1 & Raymunida insulata & Seychelles Is. & Cepros & unnumbered & AF 283884 \\
\hline MRH1 & Munida rhodonia & New Caledonia & Halipro 1 & 854 & AF 283885 \\
\hline MRH2 & Munida rhodonia & New Caledonia & Halipro 1 & 854 & AF 283886 \\
\hline MRU1 & Munida rubrodigitalis & New Caledonia & Biocal & 52 & AF 283887 \\
\hline AIN1 & Agononida incerta & New Caledonia & Bathus 3 & 824 & AF 283888 \\
\hline AIN2 & Agononida incerta & New Caledonia & Bathus 3 & 824 & AF 283889 \\
\hline
\end{tabular}

tochondrial DNA sequences have been used in many groups of decapods: Penaeidae (Palumbi and Benzie, 1991; Baldwin et al., 1998), Nephropidae (Tam and Kornfield, 1998), Palinuridae (Sarver et al., 1998), Hippidae (Tam et al., 1996), Cancridae (Harrison and Crespi, 1999), Portunidae (Chu et al., 1999), and they have provided information for taxonomic studies and phylogenetic reconstructions. The present study examines species of Raymunida from many localities of the Pacific and Indian oceans by comparing morphological characters and a partial sequence of the cytochrome oxidase gene in the mitochondrial genome. Our objectives are (1) to study the material classified as $R$. bellior and $R$. elegantissima in order to verify the possible existence of new species, corroborating the morphological distinctions with molecular data; (2) to assess which morphological characters have a specific phylogenetic value; and (3) to validate the status of the genus Raymunida, erected on the basis of morphological characters, by comparing molecular data of its species with those of Munida Leach, 1820, and Agononida Baba and de Saint Laurent, 1996.

\section{Materials AND Methods}

The collections of Raymunida specimens in the Muséum national d'Histoire naturelle of Paris (MNHN) and National Museum of Natural History, Washington, D.C., were examined. For morphological descriptions, measurements given are of carapace length, excluding rostrum, and the terminology used mainly follows Macpherson (1994). Color notes are based on slides taken of living material. To avoid repetitious descriptions, a brief diagnosis is provided for each species, without mentioning the characters included in the generic description. Raymunida cagnetei is not included (see Macpherson and Machordom, 2000). Additional data on the geographic location of the stations are to be found in the following papers: “Albatross" Expedition (Baba, 1988), Musorstom Expeditions (Macpherson, 1994, 1996, 1999). The synonymies provided here are based on the original descriptions and on recent papers.

For molecular analysis, we used samples from several localities and species from the western Pacific (e.g., Musorstom Expeditions) and western Indian oceans (Cepros Expedition), preserved in $70 \%$ alcohol and deposited in the Muséum national d'Histoire naturelle, Paris. Specimens from the "Albatross" Expedition were not used as nucleotid sequences could not be obtained (probably they were originally preserved in Formalin); therefore, the unique specimen identified as Raymunida bellior was used only for the morphological study (see below). We also compared molecular data of the species of Raymunida with those of two species of Munida (M. rhodonia Macpherson, 1994, and M. rubrodigitalis Baba, 1994) and one species of Agononida (A. incerta (Henderson, 1888)). From each specimen, the fifth pereiopod was taken. Collection locations and number of specimens of Raymunida analysed are shown in Table 1. The sequences have been deposited in GenBank (Table 1). Platyeriocheir formosa (Chan et al., 1995) (Family Grapsidae) (GenBank Accession Numbers AF105249 and AF105250) was used as outgroup.

Total DNA was extracted from tissues preserved in ethanol. We ground the samples to a powder in liquid nitrogen before adding $600 \mu \mathrm{l}$ of CTAB lysis buffer $(2 \%$ CTAB, $1.4 \mathrm{M} \mathrm{NaCl}, 0.2 \%$ ßmercaptoethanol, $20 \mathrm{mM}$ EDTA, $0.1 \mathrm{M}$ TRIS $\mathrm{pH}=8$ ) and digesting them with proteinase $\mathrm{K}(100 \mu \mathrm{g} / \mathrm{ml})$ at $60^{\circ} \mathrm{C}$ for $2-5 \mathrm{~h}$. The rest of 
the extraction followed the phenol/chloroform method (Sambrook et al., 1989). The partial COI was amplified by polymerase chain reaction (PCR). The primers used were LCO1490 (Folmer et al., 1994), and COI-H 5'TCAGGGTGACCAAAAAATCA3' (6 bases shorter than HCO2198 of Folmer et al., 1994). The following cycles were used in the amplification: $92^{\circ} \mathrm{C}(5 \mathrm{~min}), 40 \mathrm{cy}-$ cles of $94^{\circ} \mathrm{C}(30 \mathrm{~s}), 50^{\circ} \mathrm{C}(1 \mathrm{~min}), 72^{\circ} \mathrm{C}(1 \mathrm{~min})$, and a final extension of $72^{\circ} \mathrm{C}(10 \mathrm{~min})$. The PCR mix, for a final volume of $50 \mu \mathrm{l}$, was 1-3 $\mu \mathrm{l}$ DNA, $0.5 \mu \mathrm{M}$ each primer, $0.2 \mathrm{mM}$ of each dNTP, $2 \mathrm{mM} \mathrm{MgCl}_{2}, 1 \mathrm{U}$ Tth DNA polymerase (Biotools), the corresponding buffer and $\mathrm{ddH}_{2} \mathrm{O}$. The products were visualised under UV light in $1.5 \%$ agarose gels stained with ethidium bromide, with a co-migrating $100 \mathrm{bp}$ ladder molecular-weight marker to confirm the correct amplification. The amplified fragments (around $700 \mathrm{bp}$ ) were purified in "Biotools" columns for the sequencing of both strands (using the same primers as for the amplification). Sequence gels were run on an ABI 377 DNA sequencer (Applied Biosystems).

The sequences obtained were aligned and verified with the forward and reverse overlap sequences with the Sequencher program (Gene Code Corporation). The translation to proteins was also verified with this program and with MacClade (Maddison and Maddison, 1992), where we designated each position in the codons.

Nucleotide saturation was analysed by plotting transition/transversion rate against uncorrected $\mathrm{p}$ divergence values. The sequences analysed followed the principles of MP (maximum parsimony), NJ (neighbour joining), and ML (maximum likelihood). The best model of evolution that fit our data was obtained using the program Model Test 2.1 (Posada and Crandall, 1998). Thus, the GTR (General Time Reversible model, Lavane et al., 1984, Rodríguez et al., 1990) distance was used. The parsimony analyses were performed by heuristic search with TBR branch swapping and 10 replicates of random addition of taxa. The maximum likelihood approach was performed using Quartet Puzzling analysis (with 1,000 replications). The PAUP* (Swofford, 2000) package was used for these treatments. Transitions/transversions ratio was estimated using maximum likelihood approach. To determine whether a particular tree topology is a significantly worse explanation of the data than an alternative tree, we used both Wilcoxon signed-ranks (Templeton, 1983) and Kishino-Hasegawa (Kishino and Hasegawa, 1989) tests, as implemented in PAUP.

\section{RESULTS}

\section{Systematics \\ Raymunida bellior \\ (Miyake and Baba, 1967)}

Fig. 1A-D

Munida bellior Miyake and Baba, 1967, p. 216, figs. 3, 4.-Baba, 1988, p. 90.

not Munida bellior.-Macpherson, 1994, p. 450, fig. 66 (color) [in part = Raymunida confundens, new species; $R$. dextralis, new species; $R$. elegantissima (de Man, 1902)]; 1996, p. 390, fig. 12 (color) [in part $=$ R. elegantissima (de Man, 1902); R. erythrina, new species].

Material Examined.-Philippines. Between Masbate and Leyte. "Albatross," stn. 5398, 209 m: 1 female, 9.5 mm.

Diagnosis. - Carapace with transverse ridges with some very short, not iridescent, setae, without long iridescent simple setae. Gastric region with row of 4 pairs of epigastric spines. One parahepatic, 3 branchial anterior, and 1 postcervical spine on each side. Second and third abdominal tergites without long iridiscent simple setae, with 1 main continuous transverse stria. First segment of antennal peduncle with 1 long distal spine on mesial margin, overreaching antennal peduncle and reaching end of basal segment of antennular peduncle (excluding distal spines); second segment with 2 long distal spines, mesial distal spine slightly longer than lateral spine, overreaching antennal peduncle; third segment unarmed. Merus of third maxilliped unarmed on extensor margin. Chelipeds with numerous long plumose setae. Palm 0.75 fingers length. Palm with several spines scattered on mesial and dorsal sides and 1 row of dorsolateral spines, continuing along proximal half of fixed finger; movable finger with 1 spine on proximal part of mesial margin. Second pereiopod 2.4 times carapace length; merus as long as carapace, about 7 times as long as high, 3 times carpus length and about 1.3 times propodus length; propodus about 9 times as long as high and 2.7 times dactylus length. Merus with spines along dorsal border, increasing in size distally, ventral margin with few distal spines. Carpus with some dorsal spines and 1 distoventral spine. Propodus with 5 movable ventral spines. Dactylus short, with dorsal margin slightly convex, curving distally, ventral border indented, with 8 movable spinules along entire ventral margin. Merocarpal articulation of third walking leg slightly overreaching frontal margin of carapace and not exceeding sinus between rostral and supraocular spines.

Color--(from Miyake and Baba, 1967) Ground color of carapace and abdomen reddish brown. Carapace with broad V-shaped band of reddish brown placed on posterior half. Proximal and distal portions of each joint of cheliped more emphasized with reddish brown color than other portions, fingers light seashell pink. Merus of each ambulatory leg with three bands of reddish brown, carpus with a single band of reddish brown at proximal portion, propodus with two bands, dactylus reddish brown.

Distribution.--Sagami Bay, Japan (type locality), Philippines, between 80 and $209 \mathrm{~m}$. 


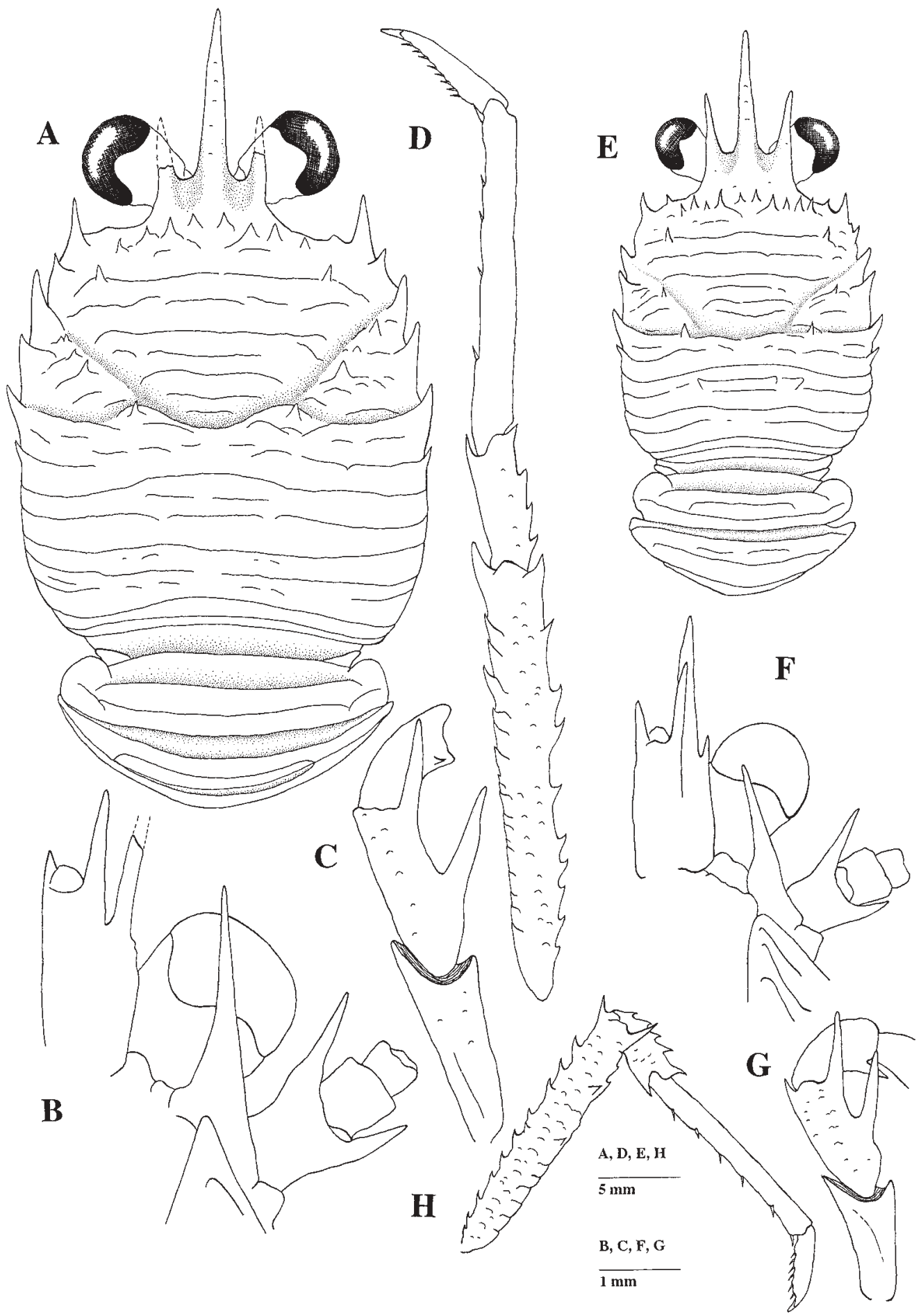

Fig. 1. A-D Raymunida bellior (Miyake and Baba). Philippines. "Albatross," stn. 5398, female $(\mathrm{CL}=9.5 \mathrm{~mm}) . \mathrm{A}$, carapace and abdomen, dorsal view; B, ventral view of cephalic region, showing antennular and antennal peduncles; $\mathrm{C}$, right third maxilliped showing ischium, merus, and carpus, lateral view; D, left first walking leg. E-H Raymunida elegantissima (de Man). Malaysia. "Albatross," stn. 5593, female $(\mathrm{CL}=6.2 \mathrm{~mm})$. E, carapace and abdomen, dorsal view; F, ventral view of cephalic region, showing antennular and antennal peduncles; G, right third maxilliped showing ischium, merus and carpus, lateral view; H, right first walking leg. (Setae not illustrated.) 


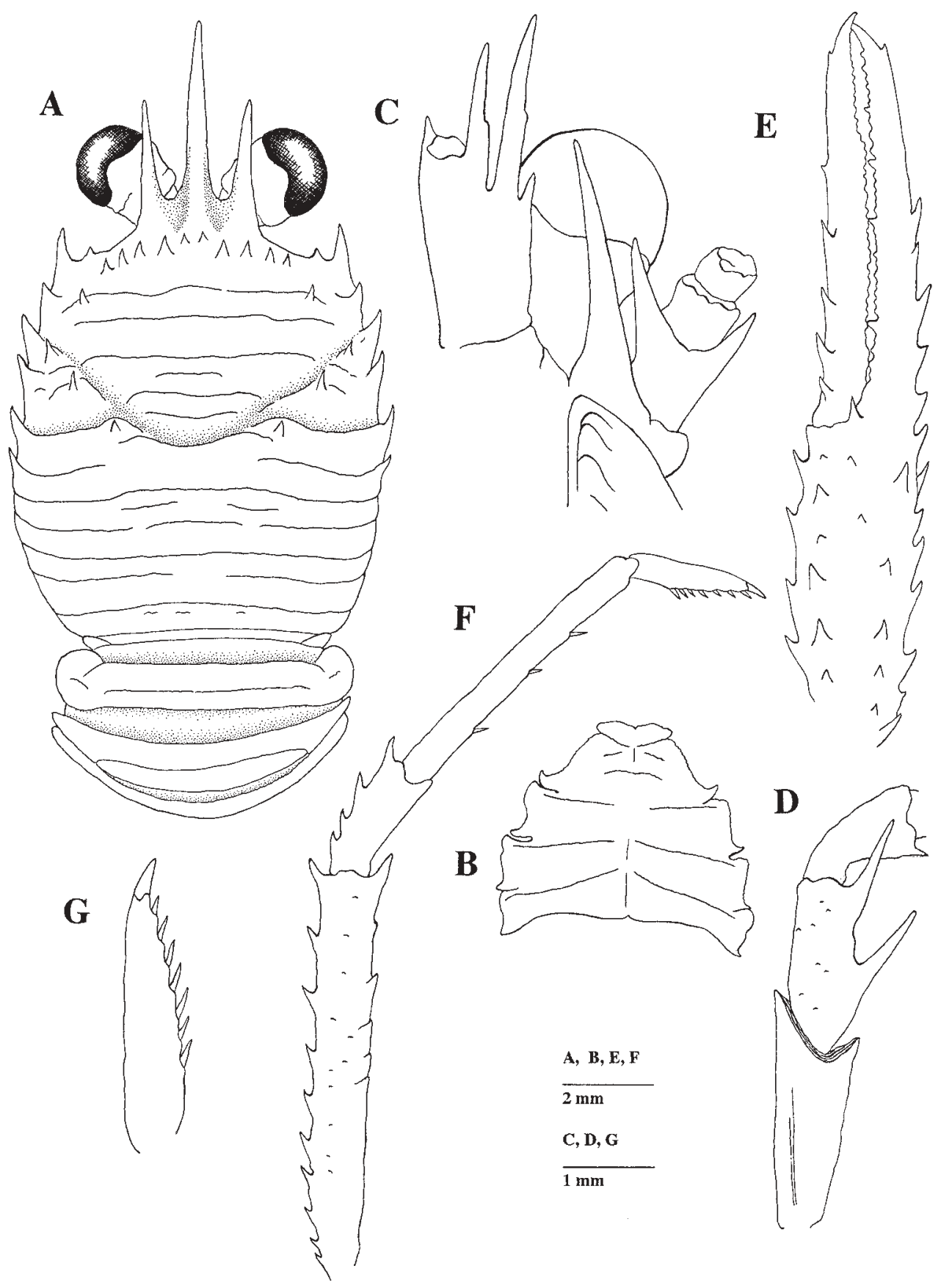

Fig. 2. Raymunida confundens, new species. Holotype, New Caledonia. Smib 8, stn 178, female (CL = $7.6 \mathrm{~mm})$. A, carapace and abdomen, dorsal view; B, sternal plastron; C, ventral view of cephalic region, showing antennular and antennal peduncles; D, right third maxilliped showing ischium, merus, and carpus, lateral view; E, right cheliped showing propodus and chela, dorsal view; F, right first walking leg, lateral view; G, dactylus of first right walking leg, lateral view (Setae not illustrated). 
Raymunida confundens, new species Fig. 2

Munida bellior-Macpherson, 1994, p. 450 (in part) [not Raymunida bellior (Miyake and Baba, 1967)].

Material Examined.-Chesterfield Islands. Musorstom 5, stn 315, 330 m: 1 male (broken). New Caledonia. Smib 8, stn 178, $400 \mathrm{~m}: 1$ female, $7.6 \mathrm{~mm}$ (holotype) (MNHN-Ga 4376).

Diagnosis. - Carapace with transverse ridges with dense very short, not iridescent, setae and few long iridescent, simple setae. Gastric region with a row of 9 or 10 epigastric spines. One parahepatic, 2 branchial anterior, and 1 postcervical spine on each side. Abdominal tergites with some long iridiscent, simple setae. Second and third tergites with 1 main continuous transverse stria. First segment of antennal peduncle with 1 long distal spine on mesial margin, clearly overreaching antennal peduncle and reaching end of basal segment of antennular peduncle (excluding distal spines); second segment with 2 strong distal spines, mesial distal spine longer than lateral spine, overreaching third antennal segment; penultimate segment unarmed. Merus of third maxilliped unarmed on extensor margin or with small distal tooth. Chelipeds with numerous long iridiscent, simple setae. Palm slightly shorter than fingers. Palm with several spines scattered on mesial and dorsal sides and 1 row of dorsolateral spines, continuing along proximal half of fixed finger; movable finger with several spines on first 0.66 of mesial margin. Second pereiopod 2.5 times carapace length; merus as long as carapace, about 7.5 times as long as high, 3 times carpus length and about 1.2 propodus length; propodus about 9 times as long as high and 2.3 times dactylus length. Merus with spines along dorsal border, increasing in size distally, ventral margin with few distal spines. Carpus with some dorsal spines and 1 distoventral spine. Propodus with 4 movable ventral spines. Dactylus short, with dorsal margin convex, curving distally, ventral border indented, with 7 movable spinules along entire ventral margin. Merocarpal articulation of third walking leg overreaching frontal margin of carapace and not reaching level of sinus between rostrum and supraocular spines.

Color-Ground color of carapace and abdomen red, with transverse white bands on striae, base of rostrum and supraocular spines white; median and lateral parts of second abdominal segment with white spots. Chelipeds and walking legs red; distal parts of cheliped fingers whitish. Walking legs with red and white bands.

Distribution.-New Caledonia and Chesterfield Islands, between 330 and $400 \mathrm{~m}$.

Etymology.-From the Latin confundo, confusion.

Raymunida dextralis, new species Fig. 3

Munida bellior.-Macpherson, 1994, p. 450 (in part), fig. 66 (color) [not Raymunida bellior (Miyake and Baba, 1967)].

Material Examined.-Loyalty Islands. Musorstom 6, stn 419, $285 \mathrm{~m}: 1$ ovig. female, $12.3 \mathrm{~mm}$ (holotype) (MNHN-Ga 2578).

Diagnosis. - Carapace with transverse ridges with dense very short, not iridescent, setae and some long iridescent, simple setae. Gastric region with a row of 4-6 pairs of epigastric spines. One parahepatic, 3 branchial anterior, and 1 postcervical spine on each side. Abdominal tergites with some long iridiscent, simple setae. Second and third tergites with 1 main continuous transverse stria. First segment of antennal peduncle with 1 long distal spine on mesial margin, clearly overreaching antennal peduncle and reaching end of basal segment of antennular peduncle (excluding distal spines); second segment with 2 long distal spines, mesial distal spine slightly longer than lateral spine, overreaching third antennal segment; penultimate segment unarmed. Merus of third maxilliped unarmed on extensor margin. Chelipeds with numerous long iridescent, simple setae. Palm slightly shorter than fingers. Palm with several spines scattered on mesial and dorsal sides and 1 row of dorsolateral spines, continuing along proximal half of fixed finger; movable finger with several spines on proximal half of mesial margin. Second pereiopod 2.5 times carapace length; merus as long as carapace, about 7 times as long as high, 3 times carpus length and about 1.2 propodus length; propodus about 10 times as long as high and 3 times dactylus length. Merus with spines along dorsal border, increasing in size distally, ventral margin with few distal spines. Carpus with some dorsal spines and one distoventral spine. Propodus with 5 movable 


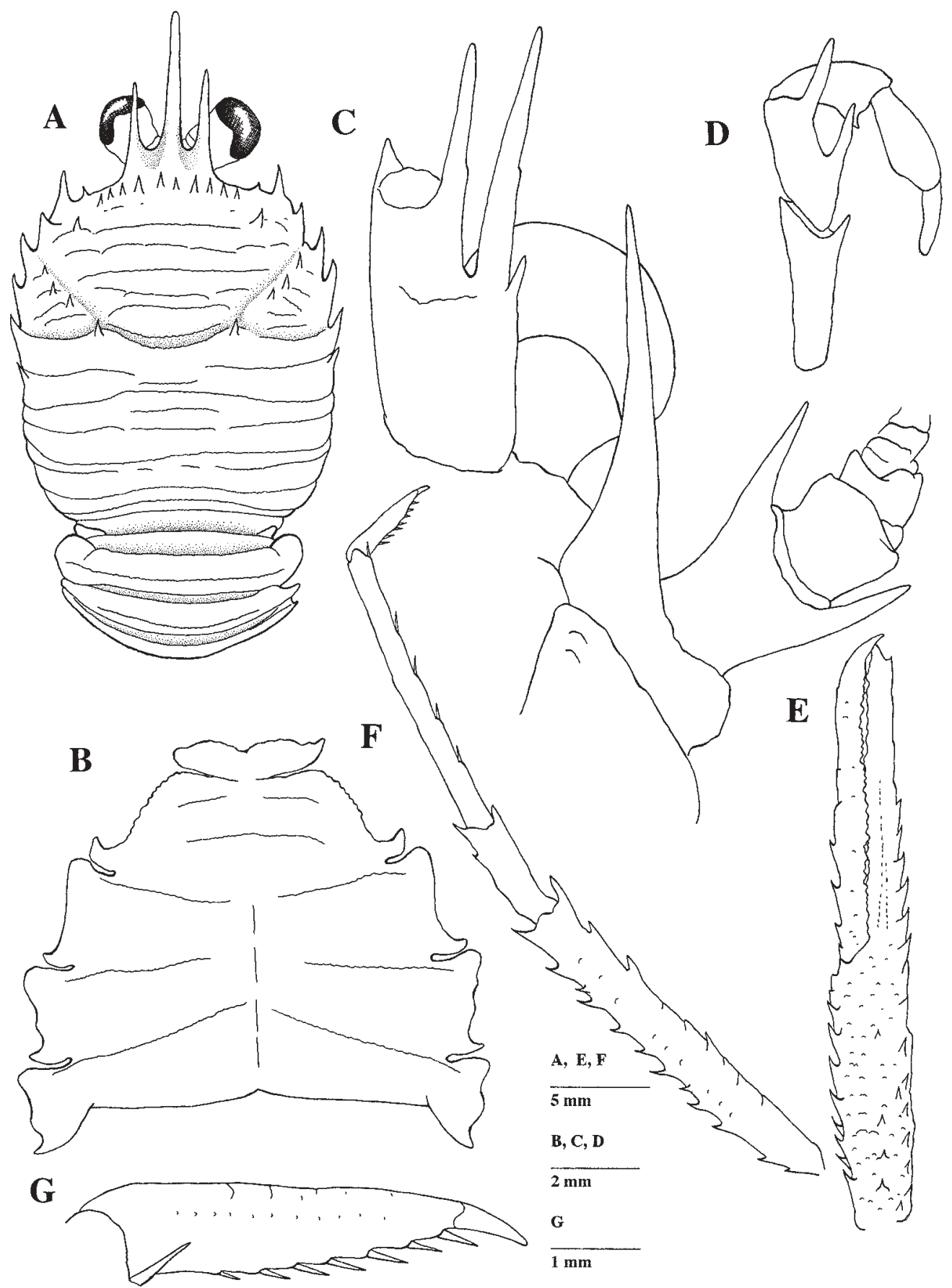

Fig. 3. Raymunida dextralis, new species. Holotype, Loyalty Islands. Musorstom 6, stn 419, ovigerous female (CL $=12.3 \mathrm{~mm}$ ). A, carapace and abdomen, dorsal view; B, sternal plastron; C, ventral view of cephalic region, showing antennular and antennal peduncles; D, right third maxilliped showing ischium, merus and carpus, lateral view; E, right cheliped showing propodus and chela, dorsal view; F, right first walking leg, lateral view; G, dactylus of first right walking leg, lateral view (Setae not illustrated). 
ventral spines. Dactylus short, with dorsal margin convex, curving distally, ventral border indented, with 6 or 7 movable spinules along entire ventral margin. Merocarpal articulation of third walking leg clearly overreaching frontal margin of carapace and reaching level of sinus between rostrum and supraocular spines.

Color-Ground color of carapace and abdomen red, with transverse white bands on striae, base of rostrum and supraocular spines white; median and lateral parts of second abdominal segment with white spots. Chelipeds red, fingers with red and white bands. Walking legs with red and white bands.

Distribution.-Loyalty Islands, $285 \mathrm{~m}$.

Etymology.-From the Latin dextrale, bracelet, in reference to the red and white bands on the walking legs.

Raymunida elegantissima (de Man, 1902) Fig. 1 E-H

Munida elegantissima de Man, 1902, p. 726, pl. 24, figs. 42, 42a, b.-Baba, 1988, p. 94.-Macpherson, 1994, p. $465 ; 1999$, p. 418 (in part).

Munida bellior.-Macpherson, 1994, p. 450 (in part); 1996, p. 390 (in part) [not Raymunida bellior (Miyake and Baba, 1967)].

Material Examined.-Malaysia. "Albatross." Off northeastern Borneo, Sibuko Bay, stn. 5593, 70 m: 1 female, $6.2 \mathrm{~mm}$. Philippines. "Albatross." Verde Island Passage, stn. 5179, $68 \mathrm{~m}$ : 1 male, $7.2 \mathrm{~mm}$.-Musorstom 1, stn 57, 96-107 m: 1 male, $4.9 \mathrm{~mm}$; 2 ovig. females, 7.2 and 7.3 $\mathrm{mm}$; 1 female, $2.6 \mathrm{~mm}$.-Musorstom 1, stn. 62, 179-194 $\mathrm{m}$ : 1 female, $3.7 \mathrm{~mm}$.-Musorstom 2, stn. 8, 85-90 m: 1 male, $8.4 \mathrm{~mm}$; 1 ovig. female, $9.3 \mathrm{~mm}$.-Musorstom 2, stn. 47, 81-84 m: 1 male, $5.3 \mathrm{~mm}$; 2 ovig. females, 9.0 and $9.8 \mathrm{~mm}$.-Musorstom 3, stn. 117, 92-97 m: 1 male, $4.5 \mathrm{~mm}$; 1 female, $2.9 \mathrm{~mm}$. New Caledonia. Lagon, stn. 640, 50-80 m: 1 ovig. female, $9.3 \mathrm{~mm}$. Chesterfield Islands. Chalcal 1, stn. 2, 80-120 m: 1 male, $5.2 \mathrm{~mm}$. Belona Island. Corail 1, without position: 1 ovig. female, $12.2 \mathrm{~mm}$. Futuna Island. Musorstom 7, stn. 498, 105-160 m: 1 female, $4.8 \mathrm{~mm}$. Vanuatu. Musorstom 8 , stn 966, 128-150 m: 2 males, 7.6 and $8.5 \mathrm{~mm} ; 1$ ovig. female, $10.3 \mathrm{~mm}$; 1 female, $8.9 \mathrm{~mm}$; 1 juvenile, $3.2 \mathrm{~mm}$. Fiji. Musorstom 10, stn. 1363, $18^{\circ} 12.4^{\prime} \mathrm{S}, 178^{\circ} 33.0^{\prime} \mathrm{E}$, 144-150 m: 1 ovig. female, $7.3 \mathrm{~mm}$.

Diagnosis. - Carapace with transverse ridges with dense, very short, not iridescent, setae and some long, iridescent, simple setae. Gastric region with row of 5 or 6 pairs of epigastric spines. One parahepatic, 1-3 branchial anterior, and 1 postcervical spine on each side. Abdominal tergites with some long, iridescent, simple setae. Second and third ter- gites with 1 main continuous transverse stria preceded by 1 secondary continuous or interrupted striae. First segment of antennal peduncle with 1 long distal spine on mesial margin, slightly overreaching antennal peduncle and not reaching end of basal segment of antennular peduncle (excluding distal spines); second segment with 2 long distal spines, mesial distal spine slightly longer than lateral spine, overreaching third antennal segment; penultimate segment unarmed. Merus of third maxilliped with distal spine on extensor margin. Chelipeds with numerous long iridiscent, simple setae. Palm half as long as fingers. Palm with several spines scattered on mesial and dorsal sides and 1 row of dorsolateral spines, continuing along fixed finger; movable finger with several spines on proximal half of mesial margin. Second pereiopod 2.5 times carapace length; merus as long as carapace, about 6.5 times as long as high, 4 times carpus length and about 1.4 times propodus length; propodus about 10 times as long as high and 2.4 times dactylus length. Merus with spines along dorsal border, increasing in size distally, ventral margin with few distal spines. Carpus with some dorsal spines and 1 distoventral spine. Propodus with 5-7 movable ventral spines. Dactylus short, with dorsal margin convex, curving distally, ventral border indented, with 6 or 7 movable spinules along entire ventral margin. Merocarpal articulation of third walking leg nearly reaching level of frontal margin of carapace.

Color-Ground color of carapace and abdomen red, with transverse white bands on main striae, base of rostrum and supraocular spines red. Chelipeds and walking legs red, without colored bands and with some small whitish spots; distal part of cheliped fingers whitish.

Distribution.-Philippines, Malaysia (type locality), New Caledonia, Chesterfield Islands, Belona Island, Futuna Island, Vanuatu, and Fiji, between 50 and $160 \mathrm{~m}$.

\section{Raymunida erythrina, new species}

Fig. 4

Munida bellior-Macpherson, 1996, p. 390 (in part), fig. 12 (color) [not Munida bellior (Miyake and Baba, 1967)].

Munida elegantissima.-Macpherson, 1999, p. 418 (in part) [not Munida elegantissima de Man, 1902]. 


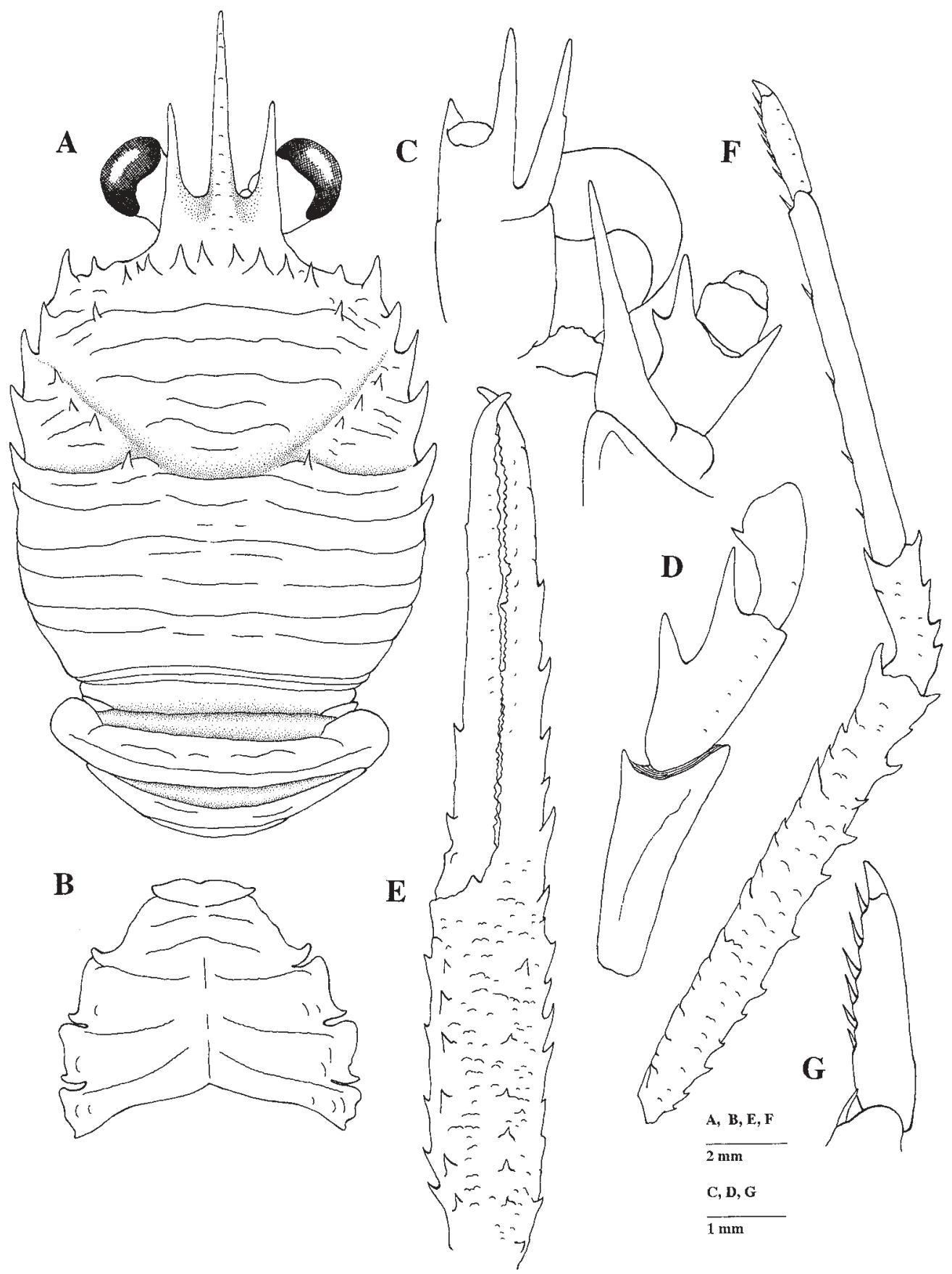

Fig. 4. Raymunida erythrina, new species. Holotype, Futuna Island. Musorstom 7, stn. 515, female $(\mathrm{CL}=9.0 \mathrm{~mm})$. A, carapace and abdomen, dorsal view; B, sternal plastron; C, ventral view of cephalic region, showing antennular and antennal peduncles; D, left third maxilliped showing ischium, merus, and carpus, lateral view; E, right cheliped showing propodus and chela, dorsal view; F, left first walking leg, lateral view; G, dactylus of first left walking leg, lateral view (Setae not illustrated). 
Material Examined.-Futuna Island. Musorstom 7, stn. 515, 224-252 m: 1 female, $9.0 \mathrm{~mm}$ (holotype) (MNHNGa 3657). Vanuatu. Musorstom 8, stn. 1077: 180-210 m: 1 ovig. female, $9.3 \mathrm{~mm}$.

Diagnosis.-Carapace with transverse ridges with very short, not iridescent setae, and few long iridescent, simple setae. Gastric region with row of 4 or 5 pairs of epigastric spines. One parahepatic, 3 branchial anterior, and 1 postcervical spine on each side. Abdominal tergites with some long iridescent, simple setae. Second and third tergites with 1 main continuous transverse stria, preceded by 1 secondary interrupted or continuous stria. First segment of antennal peduncle with 1 long distal spine on mesial margin, exceeding antennal peduncle and not reaching end of basal segment of antennular peduncle (excluding distal spines); second segment with 2 distal spines, mesial distal spine slightly longer than lateral spine, not overreaching antennal peduncle; penultimate segment unarmed. Merus of third maxilliped unarmed on extensor margin. Chelipeds with long simple setae, more abundant on mesial and lateral borders. Palm 0.75 fingers length. Palm with several spines scattered on mesial and dorsal sides and 1 row of dorsolateral spines, continuing along proximal 0.66 of fixed finger; movable finger with 2 spines on proximal part of mesial margin. Second pereiopod 2.6 times carapace length; merus longer than carapace, about 7.5 times as long as high, 4 times carpus length and about 1.4 times propodus length; propodus about 10 times as long as high and 3 times dactylus length. Merus with spines along dorsal border, increasing in size distally, ventral margin with few distal spines. Carpus with some dorsal spines and 1 distoventral spine. Propodus with 4 or 5 movable ventral spines. Dactylus short, with dorsal margin slightly convex, curving distally, ventral border with 5 or 6 movable spinules along entire margin. Merocarpal articulation of third walking leg clearly overreaching frontal margin of carapace and sinus between rostrum and supraocular spines.

Color-Ground color of carapace and abdomen reddish. Some small white spots scattered on dorsal surface of carapace and abdominal segments. Rostrum and supraocular spines reddish. Chelipeds and walking legs reddish, with small scattered white spots. Mesial and lateral border of palm and fingers whitish, white spots more numerous on distal portion of fingers.

Distribution.- Vanuatu, Futuna Island, between 180 and $252 \mathrm{~m}$.

Etymology.-From the Greek erythros, red, in reference to the ground color of the carapace and abdomen.

\section{Raymunida insulata, new species}

Fig. 5

Material Examined.-Seychelles Islands. Cepros cruise, 23.10.1987, $04^{\circ} 46.5^{\prime} \mathrm{S}, 56^{\circ} 38.4^{\prime} \mathrm{E}, 200 \mathrm{~m}$ : 1 female, 16.5 $\mathrm{mm}$ (holotype) (MNHN-Ga 4377).

Diagnosis. - Carapace with transverse ridges with some very short, not iridescent, setae, without long, iridescent, simple setae. Rostrum and supraocular spines probably regenerating. Gastric region with row of 4 pairs of epigastric spines. One parahepatic, 3 branchial anterior, and 1 postcervical spine on each side. Abdominal tergites with some long, iridescent, simple setae. Second and third tergites with 1 main continuous transverse stria. First segment of antennal peduncle with 1 long distal spine on mesial margin, exceeding antennal peduncle and reaching end of basal segment of antennular peduncle (excluding distal spines); second segment with 2 distal spines, mesial distal spine slightly longer than lateral spine, reaching end of antennal peduncle; penultimate segment unarmed. Merus of third maxilliped unarmed on extensor margin. Chelipeds with long simple setae, more numerous on mesial and lateral borders of articles. Palm 0.66 fingers length. Palm with several spines scattered on mesial and dorsal sides and 1 row of strong dorsolateral spines, continuing along fixed finger; movable finger with spines on proximal 0.66 of mesial margin. Second pereiopod 2.2 times carapace length; merus shorter than carapace, about 7 times as long as high, 2 times carpus length and about 1.4 times propodus length; propodus about 8 times as long as high and 2 times dactylus length. Merus with spines along dorsal border, increasing in size distally, ventral margin with 2 distal spines. Carpus with 3 dorsal spines and 1 distoventral spine. Propodus with 5 movable ventral spines. Dactylus short, with dorsal margin slightly convex, curving distally, ventral border with 9 movable spinules along entire margin. Merocarpal articulation of third walking 


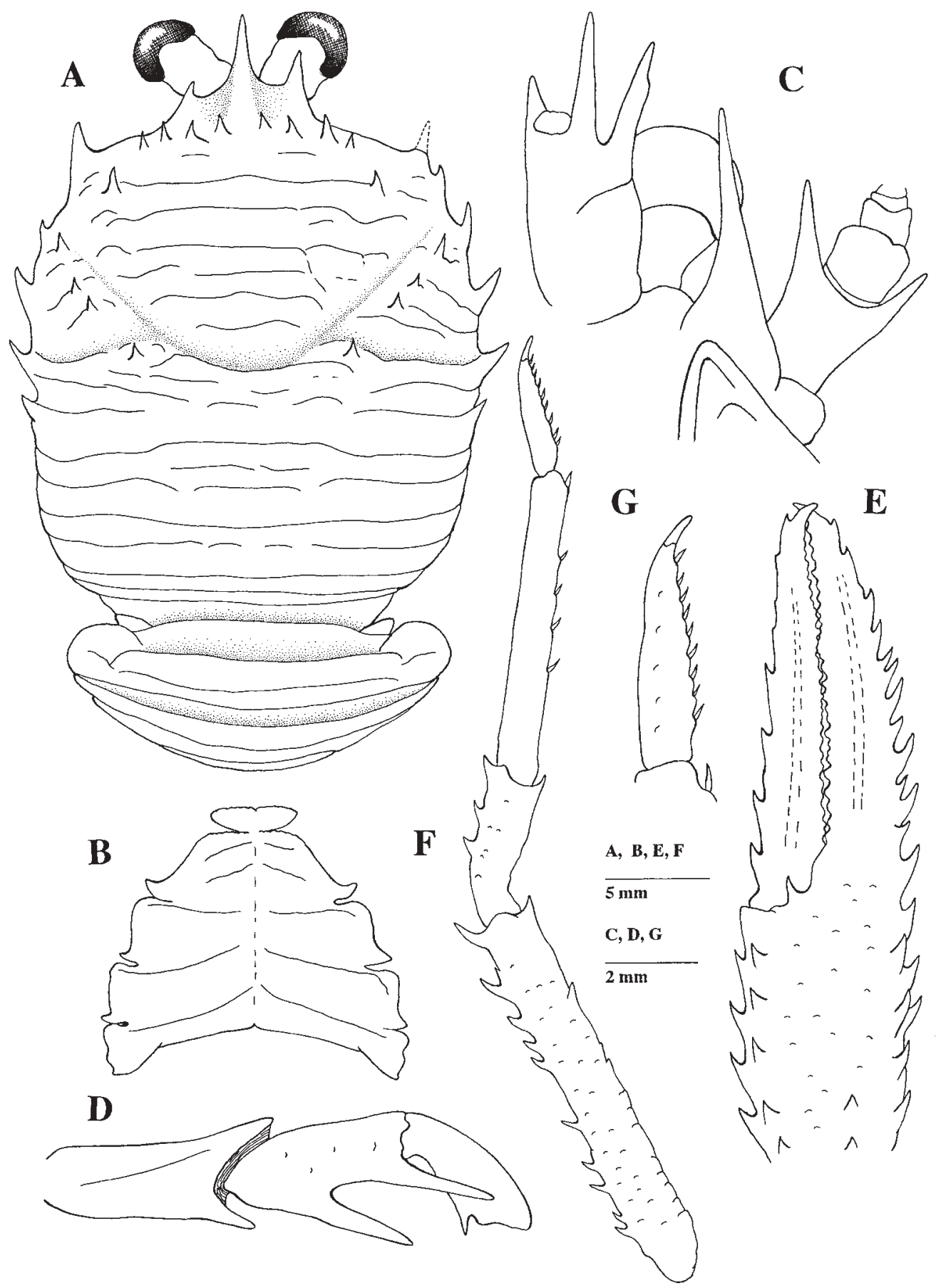

Fig. 5. Raymunida insulata, new species. Holotype, Seychelles Islands. Cepros cruise, female $(\mathrm{CL}=16.5 \mathrm{~mm})$. A, carapace and abdomen, dorsal view; B, sternal plastron; C, ventral view of cephalic region, showing antennular and antennal peduncles; D, left third maxilliped showing ischium, merus, and carpus, lateral view; E, right cheliped showing propodus and chela, dorsal view; F, right first walking leg, lateral view; G, dactylus of first right walking leg, lateral view (Setae not illustrated). 
leg slightly overreaching frontal margin of carapace and not reaching sinus between rostrum and supraocular spines.

Color--Unknown.

Distribution.-Seychelles Islands, $200 \mathrm{~m}$.

Etymology.-From the Latin insula, island, in reference to the type locality.

\section{General Remarks}

Including the descriptions given above, the genus Raymunida contains seven species: $R$. bellior, $R$. cagnetei, $R$. confundens, $R$. dextralis, $R$. elegantissima, $R$. erythrina, and $R$. insulata. These species can be distinguished by several constant morphological characters. The most useful characters are: the length of the mesial spine of the first segment of the antennal peduncle, the presence/absence of one distal spine on the extensor border of the merus of the third maxilliped, the spinulation and setal type of the chelipeds, the length of the walking legs, and the number of striae on the second and third abdominal segments. Furthermore, the color pattern can be very useful as a specific character.

The length of the mesial spine of the first segment of the antennal peduncle divided the species in two groups: Four species $(R$. bellior, $R$. confundens, $R$. dextralis, and $R$. insulata) are distinguishable by the long mesial spine of the first antennal segment, reaching or overreaching the end of the basal segment of the antennular peduncle (excluding the distal spines), whereas this spine never reaches the end of the basal segment of the antennular peduncle in the second group (R. cagnetei, $R$. elegantissima, and $R$. erythrina).

Among the species of the first group, $R$. bellior is distinguished from $R$. confundens, $R$. dextralis, and $R$. insulata by the presence of numerous plumose setae on the chelipeds, and the carapace lacks long setae dorsally, whereas in the other three species the cheliped setae are simple and the carapace has long setae dorsally. Raymunida insulata can be distinguished from $R$. confundens and $R$. dextralis by the following characters: the palms of the chelipeds each have a row of strong dorsolateral spines, continuing along the whole length of the fixed finger in $R$. insulata, whereas the spines on the fixed finger are not strong and never overreach the proximal half of the lateral margin of the fixed finger in the other two species. Raymunida confundens and $R$. dextralis are distinguishable by the length of the walking legs: the merocarpal articulation of the third walking leg does not reach the sinus between the rostrum and the supraocular spines in $R$. confundens, whereas this articulation overreaches the sinus in $R$. dextralis. The color patterns are also different as follows: In $R$. bellior the ground color of the carapace and abdomen is reddish brown, the carapace has a broad V-shaped band of reddish brown on the posterior half, and the walking legs have reddish brown bands. In $R$. dextralis the ground color of the carapace and abdomen is red, with transverse white bands on the striae; the base of the rostrum and supraocular spines are white, and the cheliped fingers and walking legs have red and white bands. The color pattern in $R$. confundens is quite similar to that of $R$. dextralis; however, the cheliped fingers and walking legs have no white bands. The color pattern in $R$. insulata is unknown.

The second group of species (R. cagnetei, $R$. elegantissima, and $R$. erythrina) also differ in several constant characters. Raymunida erythrina has the merus of the third maxilliped unarmed on the extensor margin, and the merocarpal articulation of the third walking leg clearly overreaches the frontal margin of the carapace. In the other two species the merus of the third maxilliped has a distal spine on the extensor margin, and the merocarpal articulation of the third walking leg does not reach the frontal margin of the carapace. Raymunida elegantissima and $R$. cagnetei can be distinguished by the following characters: The merocarpal articulation of the third walking leg overreaches the level of the first branchial spine of the carapace, and the second abdominal segment has a secondary stria in R. elegantissima; whereas in $R$. cagnetei the merocarpal articulation of the third walking leg only reaches the level of the first branchial spine of the carapace, and the second abdominal segment is occasionally preceded by 2 small median scales. Furthermore, the color pattern of $R$. cagnetei is different to that of R. elegantissima and R. erythrina, having wide white vertical bands along each branchial margin of the carapace and white bands on each lateral margin of the first to third abdominal somites. These vertical 
white bands are absent in the other two species. Raymunida elegantissima and $R$. erythrina have similar color patterns, although the transverse white bands on the striae of the carapace and abdominal somites are more conspicuous in $R$. elegantissima than in $R$. erythrina.

Raymunida elegantissima has also been cited in other localities of the Indian Ocean: Zanzibar and the Gulf of Mannar (as Munida alcocki Southwell, 1906) (see Baba, 1988). The specimen from Zanzibar belongs to the second group of species mentioned above (the mesial spine of the basal antennal segment does not reach the end of the basal segment of the antennular peduncle, and the merus of the third maxilliped has a distal spine on the extensor margin), and it is different from $R$. insulata from the Seychelles. Nevertheless, the specimen is damaged, and clear identification is impossible. The specimens from the Gulf of Mannar were not studied. It would be interesting to collect additional material from the Indian Ocean, in order to improve our knowledge on the taxonomic status of the genus Raymunida in this area.

\section{Key to Species of the Genus Raymunida}

1. Mesial spine of first antennal segment reaching or overreaching end of basal segment of antennular peduncle (excluding distal spines) . . . . . . . . 2

- Mesial spine of first antennal segment not reaching end of basal segment of antennular peduncle (excluding distal spines) . . . . . . . . . . . . . 5

2. Chelipeds with numerous plumose setae. Carapace lacking long setae dorsally . . . . . . . R . bellior

- Chelipeds with numerous simple setae. Carapace with some long setae dorsally . . . . . . . . . 3

3. Palm of chelipeds with row of strong dorsolateral spines, continuing along whole length of fixed finger . . . . . . . . . . . . . . . .

- Palm of chelipeds with row of small dorsolateral spines, continuing along proximal half of fixed finger . . . . . . . . . . . . . . . . . . . . . . . 4

4. Merocarpal articulation of third walking leg not reaching sinus between rostrum and supraocular spines................ confundens

- Merocarpal articulation of third walking leg overreaching sinus between rostrum and supraocular spines. . . . . . . . . . . . dextralis

5. Merus of third maxilliped unarmed on extensor margin. Merocarpal articulation of third walking leg clearly overreaching frontal margin of carapace $R$. erythrina

- Merus of third maxilliped with distal spine on extensor margin. Merocarpal articulation of third walking leg not reaching frontal margin of carapace

6. Merocarpal articulation of third walking leg overreaching level of first branchial spine of carapace.
Second abdominal segment has one secondary stria . . . . . . . . . . . . R. elegantissima

- Merocarpal articulation of third walking leg reaching level of first branchial spine of carapace. Second abdominal segment without secondary stria

R. cagnetei

\section{Genetic Data}

Among the 21 specimens sequenced, 16 haplotypes were distinguished. The globally empirical nucleotide composition was $\mathrm{A}=$ $27.75 \%, \mathrm{C}=18.03 \%, \mathrm{G}=17.55 \%$ and $\mathrm{T}=$ $36.67 \%$. There was a significant bias $(P<$ $0.001)$ in the nucleotide composition in the third codon positions $(\mathrm{A}=42.47 \%, \mathrm{C}=$ $9.28 \%, \mathrm{G}=3.20 \%, \mathrm{~T}=45.05 \%)$ as usual for crustacean species (Hillis et al., 1996; Baldwin et al., 1998; Sarver et al., 1998 and references therein). The alignment of $657 \mathrm{nu}-$ cleotides sequenced did not provide any gap among the ingroup, nor with respect to the outgroup. Among the 212 informative sites, the third position was the most informative (78.3\%), followed by the first $(19.34 \%)$. The transition/transversion ratio, evaluated by ML on the parsimony analysis, ts/tv $=2.16, \gamma=$ 1.71 , and the proportion of invariable sites was 0.59 . All these characteristics indicate that these were mitochondrial sequences rather than nuclear pseudogenes (Zhang and Hewitt, 1996).

The intraspecific divergences averaged $\bar{p}=$ $0.24 \%$, and the interspecific (including only Raymunida) $\overline{\mathrm{p}}=10.95 \%$ (with a minimum of $7.6 \%$ between $R$. elegantissima and $R$. cagnetei, and a maximum of $13.2 \%$ between $R$. confundens and $R$. elegantissima). Interspecific distance between the two Munida species analysed was $\overline{\mathrm{p}}=6.1 \%$. The divergences among Raymunida and the outgroup (Platyeriocheir formosa) or Agononida were $\overline{\mathrm{p}}=17.88 \%$ and $17.73 \%$, respectively. The mean divergence among Raymunida and Munida species was slightly smaller $(\overline{\mathrm{p}}=$ $16.89 \%$ ) (Table 2). No saturation was found in our markers in any position (Fig. 6).

The three methods of phylogenetic reconstruction recovered the same topology. The monophyly of the genus Raymunida was fully supported, with high bootstraps (99 or 100) (Fig. 7). Within Raymunida, both ML and NJ methods showed a basal cluster constituted by three species: $R$. insulata, $R$. dextralis, and $R$. confundens, the last two forming a sister group. Nevertheless, the MP tree did not clar- 


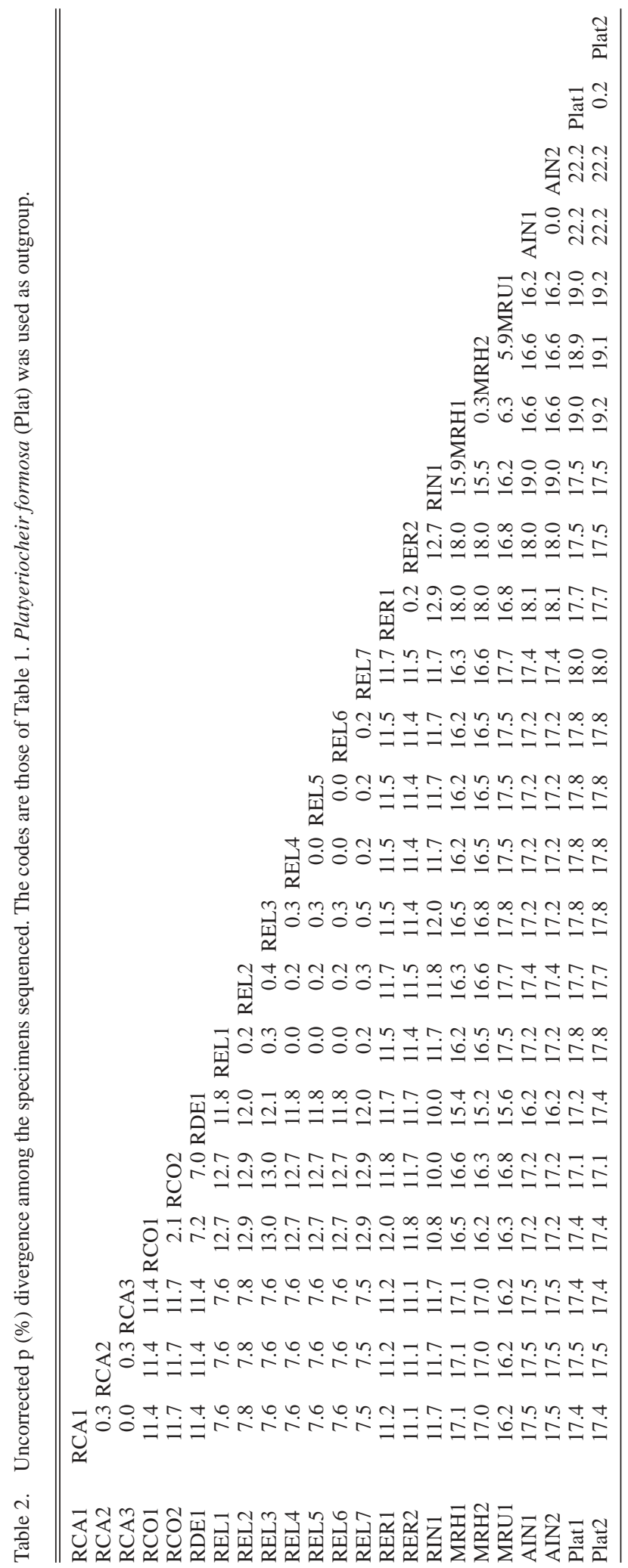




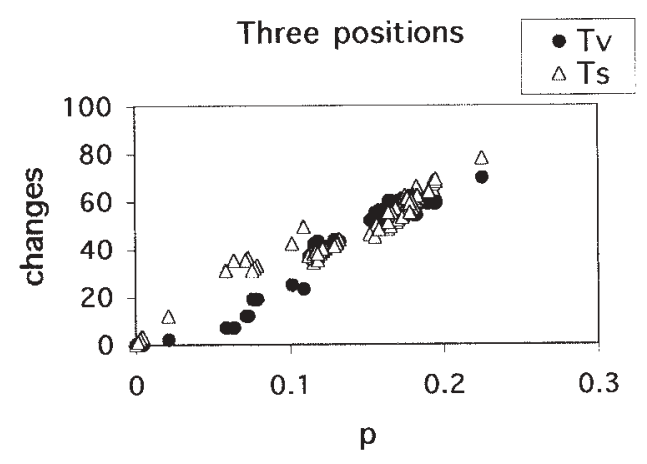

2nd positions

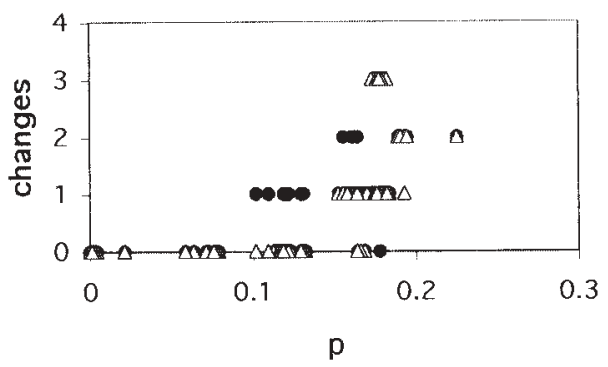

1 st positions

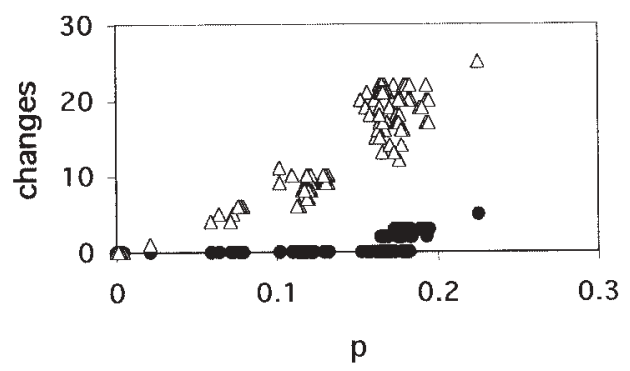

3rd positions

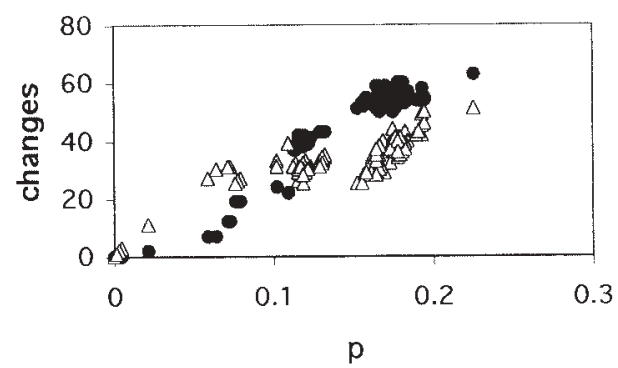

Fig. 6. Relationship between uncorrected mean divergence (p) between pairs of taxa and the number of transitional (ts) and transversional (tv) changes at different codon positions.

ify the relationships between these three species (although $R$. confundens and $R$. dextralis always constituted a sister group) and the other branch, which grouped the remaining three species ( $R$. elegantissima, $R$. cagnetei, and $R$. erythrina). The phylogenetic relationships of these last three species were supported by the three methods: $R$. erythrina showed a basal position, and $R$. elegantissima and $R$. cagnete $i$ were clustered as a sister group. The specimens of the two Munida species analysed were always clustered as a sister group of Agononida. Nevertheless, neither KishinoHasegawa nor Wilcoxon signed-rank tests revealed significant differences ( $P$ between 0.20 and 0.38 ) between the parsimony trees obtained by comparing the two hypotheses: that Munida is the sister group of Agononida (as in the tree presented) or that Munida could be the sister group of Raymunida. The trees obtained for this last hypothesis were longer than those presented here (523 steps instead of 517), but not significantly worse.

\section{DisCUSSION}

The species of Raymunida can be identified by subtle morphological characters and are corroborated by mitochondrial sequences data. Thus, the sequence divergences confirm the specific value of some morphological characters (e.g., length of the mesial spine on the basal antennal segment, length of the walking legs). Furthermore, they confirm the importance of color patterns as diagnostic characters, as pointed out for other species of decapods differing little in morphology (Knowlton, 1993; Chan and Chu, 1996; Sarver et al., 1998).

The use of molecular information in species that are difficult to distinguish morphologically may aid taxonomic studies (Avise, 1994) and the analysis of population subdivisions (Tam et al., 1996; Chu et al., 1999). Furthermore, nucleotide sequence divergences can identify characters that can reflect the phylogenetic history (Avise, 1994; Patterson et al., 1993). The two main groups of species based on COI sequences (Raymunida elegantissima $-R$. cagnete $-R$. erythrina and $R$. confundens $-R$. dextralis $-R$. insulata) are differentiated by the length of the mesial spine on the basal antennal segment. Other morphological characters (e.g., merus of the third maxilliped unarmed vs. armed on the 


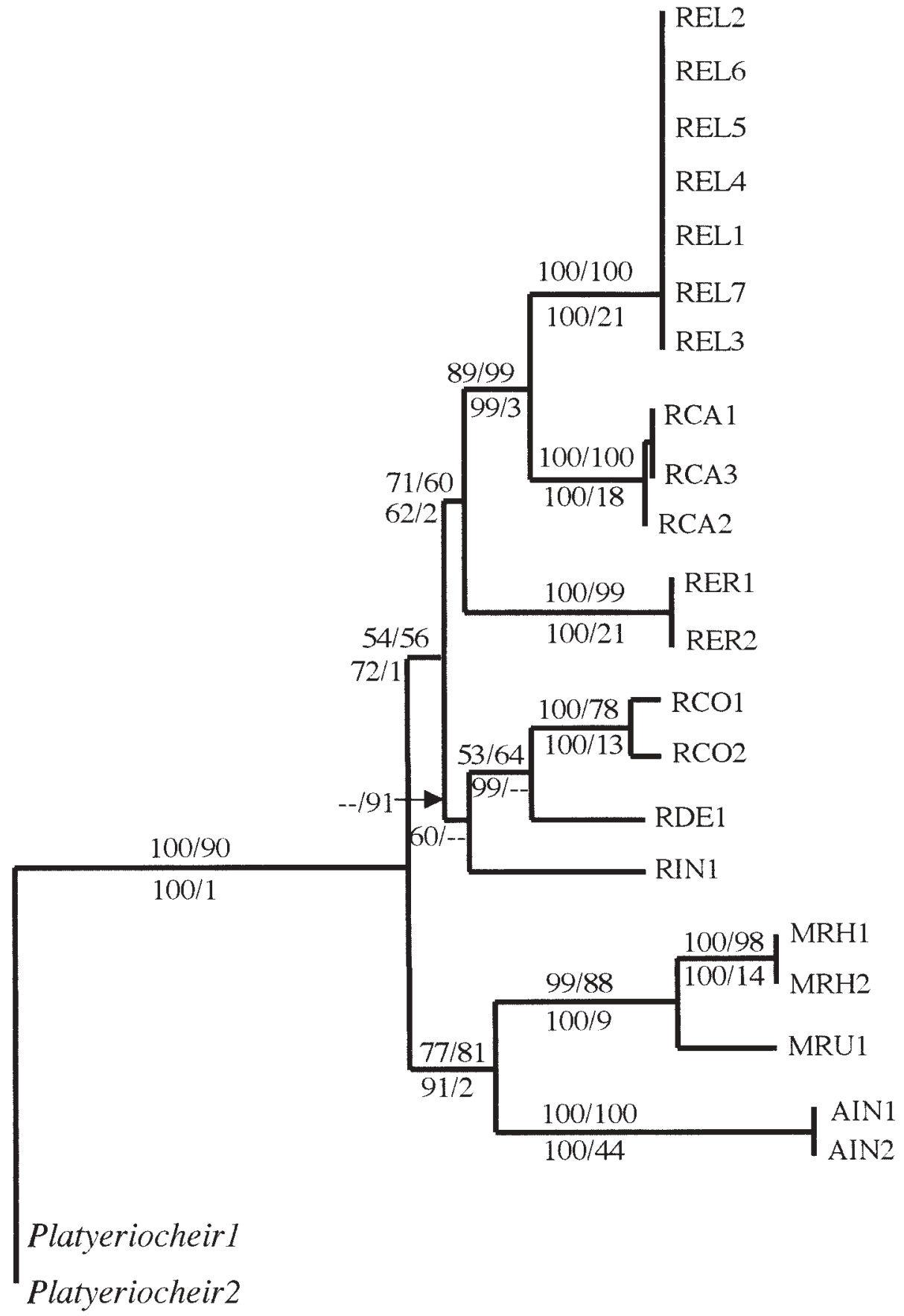

-- 0.001 changes

Fig. 7. Neighbour-joining tree based on GTR distances. Numbers above branches represent the bootstrap values obtained for 1,000 replications for MP (maximum parsimony) and ML (maximum likelihood); numbers below branches indicate those for NJ (neighbour joining), and Decay indices. When a particular branch was not recovered by a certain method, two hyphens replace the corresponding bootstrap or Decay value. The codes are those of Table 1. Platyeriocheir formosa was used as outgroup. 
extensor margin, length of the walking legs) can also have an additional phylogenetic value. Following the sequence analysis, three different divergence ranges could stand out. A divergence of $0.2 \%$ was found among the $R$. elegantissima specimens analysed, inhabiting localities separated geographically by thousands of kilometers. This divergence was 10 times greater $(2.1 \%)$ between two specimens of $R$. confundens from New Caledonia and Chesterfield, and finally, about $12 \%$ mean divergence differentiated $R$. elegantissima from $R$. confundens and $R$. erythrina, species clearly distinguishable by morphological characters. These divergence ranges are similar to those found for other studies on decapods at the same taxonomic levels (e.g., Palumbi and Benzie, 1991; Sarver et al., 1998; Harrison and Crespi, 1999; Chu et al., 1999). However, they are difficult to explain considering that these three species can be found in sympatry, although the first prefers shallower waters, if they shared a common biogeographical history. Although the biology of these species is practically unknown, it would be interesting to examine whether the mechanisms of larval dispersion or their physiology can explain such distributional patterns and degree of differentiation, as observed in other decapods (Knowlton and Weigt, 1998).

Previous data showed an important conservation in morphological or allozymic characters for Decapoda. In some cases, the morphological description could be posterior to the genetic characterization (Sarver and Foltz, 1993). For Penaeus species, in which genetic diversity based on electrophoretic analysis of allozymes is low, the divergence is between $8 \%$ and $24 \%$ for the partial sequences of COI (Baldwin et al., 1998) or 11\% for 16S (García Machado et al., 1993). We found high divergences between the species of Raymunida analysed, which were consistent with the morphological diagnostic characters. Nevertheless, in the translation of our sequences, only one amino acid changed in one population, within the ingroup. The COI is considered one of the most conservative genes in the mitochondrial genome with respect to the amino acid substitutions (Black et al., 1997). Palumbi and Benzie (1991), working on penaeid shrimp, suggested two possible explanations for the incongruence found between morphology and molecular markers: either the mitochondrial DNA has a faster evolution rate in shrimp, or the rate of morphological divergence might be slow, possibly due to stabilizing selection on morphological or ecological characters. According to our results, this stabilizing selection may also act on proteins. The close relationships between the species studied here and some biogeographic conditions, as could happen in other Decapoda (Knowlton, 1993), could explain this morphological and allozymic stabilizing selection, while the phylogenetic relationships can be followed by the silent substitutions occurring in the DNA.

With the present data, the three methods employed for phylogenetic reconstruction agreed on the proposed monophyly of Raymunida and its differentiation with respect to Munida (in which Raymunida species were previously included) and Agononida. Only the clustering of $R$. insulata (the only species analysed from the Indian Ocean) differed in the trees obtained, because the MP could not resolve its position with high confidence. This "less robust" condition of the MP analysis was found also by Baldwin et al. (1998) in their Penaeus study, and it was attributed to the sensitivity of this method to the rate variation (Nei, 1987). Nevertheless, the Decay Index also indicated that the possible dichotomy grouping $R$. insulata with $R$. dextralis/ $R$. confundens was not strongly supported by our data.

The importance of morphology versus molecular data to resolve the phylogeny of a group is still a source of controversy (e.g., Avise, 1994). Although additional works, including more specimens and species of related genera, are necessary, the results found in the present study illustrate a case where the taxonomic key based on morphological characters and the molecular tree are congruent and emphasize the importance of subtle characters (e.g., length of the mesial spine on the basal antennal segment, length of the walking legs, merus of the third maxilliped unarmed/armed) in the knowledge of the evolution of these species.

\section{ACKNOWLEDGEMENTS}

We are greatly indebted to A. Crosnier and B. Richer de Forges of ORSTOM for placing at our disposal the main part of the material examined. We thank R. Lemaitre (National Museum of Natural History, Washington) and Paul Clark (The Natural History Museum, London) for providing specimens of different species and localities. We also thank I. Uriz for her valuable suggestions and 
A. Montilla for skillful technical assistance. The species have been illustrated by J. Macpherson.

\section{LiTERATURE CiTED}

Avise, J. C. 1994. Molecular Markers, Natural History and Evolution. Chapman \& Hall, New York. 511 pp.

Baba, K. 1988. Chirostylid and Galatheid Crustaceans (Decapoda: Anomura) of the "Albatross" Philippine Expedition, 1907-1910.-Researches on Crustacea, Special Number 2: 1-203.

1994. Deep-sea Galatheid crustaceans (Anomura: Galatheidae) collected by the 'Cidaris I' expedition off central Queensland, Australia.-Memoirs of the Queensland Museum 35: 1-21.

— capoda: revision of the genus Bathymunida Balss, 1914, and description of six new related genera (Galatheidae). Pp. 433-502 in A. Crosnier, ed. Résultats des Campagnes MUSORSTOM. Vol. 15. Mémoires du Muséum national d'Histoire naturelle 168.

Baldwin, J. D., A. L. Bass, B. W. Bowen, and W. H. Clark, Jr. 1998. Molecular phylogeny and biogeography of the marine shrimp Penaeus.-Molecular Phylogenetics and Evolution 10: 399-407.

Black, M. B., K. M. Halanych, P. A. Y. Maas, W. R. Hoeh, J. Hashimoto, D. Desbruyères, R. A. Lutz, and R. C. Vrijenhoek. 1997. Molecular systematics of vestimentiferan tubeworms from the hydrothermal vents and cold-water seeps.-Marine Biology 130: 141-149.

Chan, T. Y., and K. H. Chu. 1996. On the different forms of Panulirus longipes femoristriga (von Martens, 1872) (Crustacea: Decapoda: Palinuridae), with description of a new species.- Journal of Natural History 30: 367-387.

- M. S. Hung, and H. P. Yu. 1995. Identity of Eriocheir recta (Stimpson, 1858) (Decapoda: Brachyura), with description of a new crab from Taiwan.-Journal of Crustacean Biology 15: 301-308.

Chu, K. H., J. Tong, and T. Y. Chan. 1999. Mitochondrial cytochrome oxidase I sequence divergence in some Chinese species of Charybdis (Crustacea: Decapoda: Portunidae).-Biochemical Systematics and Ecology 27: 461-468.

de Man, J. G. 1902. Die von Herrn Professor Kükenthal im indischen Archipel gesammelten Dekapoden und Stomatopoden. Pp. 467-929 in Kükenthal, ergebnisse einer zoologischen. Forschungsreise in den Molukken und Borneo. Abhandlungen der Senckenbergischen Naturforschenden Gesellschaft 25.

Folmer, O., M. Black, W. Hoeh, R. Lutz, and R. Vrijenhoek. 1994. DNA primers for amplification of mitochondrial cytochrome $c$ oxidase subunit I from diverse metazoan invertebrates.-Molecular Marine Biology and Biotechnology 3: 294-299.

García Machado, E., N. Dennebouy, M. Oliva Suárez, J. C. Mounolou, and M. Monnerot. 1993. Mitochondrial 16S-rRNA gene of two species of shrimps: sequence variability and secondary structure.-Crustaceana 65 : 279-286.

Harrison, M. K., and B. J. Crespi. 1999. Phylogenetics of Cancer crabs (Crustacea: Decapoda: Brachyura).Molecular Phylogenetics and Evolution 12: 186-199.

Henderson, J. R. 1888. Report on the Anomura Collected by H.M.S. Challenger During the Years 1873-76.- Report on the scientific results of the voyage of H.M.S. Challenger during the years 1873-1876, Zoology, 27: vi +221 pp., 21 pls.
Hillis, D. M., C. Morittz, and B. K. Mable. 1996. Molecular Systematics. Second edition. Sinauer Associates, Sunderland, Massachusetts. 655 pp.

Kishino, H., and M. Hasegawa. 1989. Evaluation of the maximum likelihood estimate of the evolutionary tree topologies from DNA sequence data, and the branching order in Hominoidea.- Journal of Molecular Evolution 29: 350-353.

Knowlton, N. 1993. Sibling species in the sea.-Annual Review of Ecology and Systematics 24: 189-216. , and L. A. Weigt. 1998. New dates and new rates for divergence across the Isthmus of Panama.-Proceedings of the Royal Society of London B 265: 2257-2263.

Lavane C., G. Preparata, C. Sacone, and G. Serio. 1984. A new method for calculating evolutionary substitution rates.-Journal of Molecular Evolution 20: 86-93.

Leach, W. E. 1820. Galatéadées.-Dictionaire des Sciences Naturelles, Paris 18: 49-56.

Macpherson, E. 1994. Crustacea Decapoda: studies on the genus Munida Leach, 1820 (Galatheidae) in New Caledonia and adjacent waters with descriptions of 56 new species. Pp. 421-569 in A. Crosnier, ed. Résultats des Campagnes MUSORSTOM. Vol. 12. Mémoires du Muséum national d'Histoire naturelle 161.

. 1996. Crustacea Decapoda: species of the genera Munida Leach, 1820 and Paramunida Baba, 1988 (Galatheidae) from the seas around the Wallis and Futuna Islands. Pp. 387-421 in A. Crosnier, ed. Résultats des Campagnes MUSORSTOM. Vol. 15. Mémoires du Muséum national d'Histoire naturelle 168.

- 1999. Crustacea Decapoda: species of the genera Agononida Baba \& de Saint Laurent, 1996 and $M u$ nida Leach, 1820 (Galatheidae) collected during the MUSORSTOM 8 cruise in Vanuatu. Pp. 407-426 in A. Crosnier, ed. Résultats des Campagnes MUSORSTOM. Vol. 20. Mémoirs du Muséum national d'Histoire naturelle 180.

- , and A. Machordom. 2000. Raymunida, new genus (Decapoda: Anomura: Galatheidae) from the Indian and Pacific Oceans.- Journal of Crustacean Biology 20, Special Number 2: 253-258.

Maddison, W. P., and D. R. Maddison. 1992. "MacClade: Analysis of Phylogeny and Character Evolution", version 3.05. Sinauer Associates, Inc., Sunderland, Massachusetts.

Miyake, S., and K. Baba. 1967. New and rare species of the family Galatheidae (Crustacea, Anomura) from the Sagami Bay in the collection of the Biological Laboratory, Imperial Household, Japan.-Journal of the Faculty of Agriculture, Kyushu University 14: 213-224.

Nei, M. 1987. Molecular Evolutionary Genetics. Columbia University Press, New York. 512 pp.

Palumbi, S. R., and J. Benzie. 1991. Large mitochondrial DNA differences between morphologically similar Penaeid shrimp.-Molecular Marine Biology and Biotechnology 1: 27-34.

Patterson, C., D. M. Williams, and C. J. Humphries. 1993. Congruence between molecular and morphological phylogenies.-Annual Review of Ecology and Systematics 24: 153-188.

Posada, D., and K. A. Crandall. 1998. Model test: testing the model of DNA substitution.-Bioinformatics 14: 817,818 .

Rodríguez, R., J. L. Oliver, A. Marín, and J. R. Medina. 1990. The general stochastic model of nucleotide substitution.- Journal of Theoretical Biology 142: 485-501. 
Sambrook, J., E. F. Fritsch, and T. Maniatis. 1989. Molecular Cloning: A Laboratory Manual, Second edition. Cold Spring Harbor Laboratory Press, Cold Spring Harbor, New York.

Sarver, S. K., and D. W. Foltz. 1993. Genetic population structure in species complex of blue mussels (Mytilus spp.).-Marine Biology 117: 105-112.

, J. D. Silberman, and P. J. Walsh. 1998. Mitochondrial DNA sequence evidence supporting the recognition of two subspecies or species of the Florida spiny lobster Panilurus argus. - Journal of Crustacean Biology 18: 177-186.

Southwell, T. 1906. Report on the Brachyura and Anomura collected by Professor Herdman, at Ceylon, in 1902. Pp. 211-224 in W. A. Herdman, ed. Report to Government of Ceylon on the Pearl Oyster Fisheries of the Gulf of Mannar 5.

Swofford, D. L. 2000. "PAUP*: Phylogeny Analysis Using Parsimony (*and other methods)", version 4.0b3. Sinauer Associates, Inc., Sunderland, Massachusetts.
Tam, Y. K., and I. Kornfield. 1998. Phylogenetic relationships of clawed lobster genera (Decapoda: Nephropidae) based on mitochondrial 16S rRNA gene sequences.- Journal of Crustacean Biology 18: 138-146. , and F. P. Ojeda. 1996. Divergence and zoogeography of mole crabs, Emerita spp. (Decapoda: Hippidae), in the Americas.-Marine Biology 125: 489-497.

Templeton, A. R. 1983. Phylogenetic inference from restriction endonuclease cleavage site maps with particular reference to the evolution of humans and the apes.-Evolution 37: 221-244.

Zhang, D. X., and G. M. Hewitt. 1996. Nuclear integrations: challenges for mitochondrial DNA markers.Trends in Ecology and Evolution 11: 247-251.

RECEIVED: 10 April 2000.

ACCEPTED: 8 November 2000. 